\title{
PERBEDAAN KETERAMPILAN BERPIKIR KREATIF DITINJAU DARI EMOSI ANAK DALAM BERMAIN KONSTRUKTIF
}

\author{
TARULI MARITO SILALAHI \\ Universitas Sari Mutiara Indonesia, Medan, Indonesia \\ Email: Taruli766hi@gmail.com \\ MEI LYNA GIRSANG \\ Universitas Sari Mutiara Indonesia, Medan, Indonesia \\ Email: girsangcantik@gmail.com
}

META BR GINTING

STKIP Kristen Wamena

Email: metamunthe31@gmail.com

Article received: 08 Juli 2020, Review process: 11 Agustus 2020,

Article Accepted: 18 September 2020, Article published: 30 September 2020

\begin{abstract}
Creative thinking skills can be developed early. Emotions play a role in shaping children's creative thinking skills. The purpose of this study is to analyze the differences early childhood creative thinking skills in terms of their emotional state through constructive play activities. This research is quantitative descriptive research. The study population is all children in group B aged 5-6 years totaling 80 childrens. Sampling is Purposive Sampling technique. The study was conducted at the Anak Raja Kindergarten in Medan. Data collection techniques using portfolio and observation techniques. Portfolio data were analyzed descriptively while observation data were analyzed to test hypotheses with Independent T-Test using SPSS 23. The results showed that the average creative thinking skills of children who play constructive with positive emotions were higher with an average value of 15.12 or located in the creative category. While the creative thinking skills of children with negative emotions in constructive play are categorized as less creative, because they obtain an average score of 9.28. Independent T-Test parametric test results are Sig. (2-tailed) $0.00<$ from 0.05 so it was decided that Ha which reads "There are differences in the creative thinking skills of children who play constructive with positive emotions with children who play constructive with negative emotions" are accepted. This research concludes that positive emotions greatly affect children's creative thinking skills.
\end{abstract}

Keywords: Creative Thinking Skills, Emotion, Constructive Play 


\section{Abstrak}

Keterampilan berpikir kreatif dapat ditumbuhkembangkan sejak dini. Emosi berperan dalam membentuk keterampilan berpikir kreatif anak. Tujuan penelitian ini untuk menganalisis perbedaan keterampilan berpikir kreatif anak usia dini ditinjau dari kondisi emosinya melalui kegiatan bermain konstruktif. Penelitian ini merupakan penelitian deskriptif kuantitatif. Populasi penelitian adalah seluruh anak kelompok B usia $5-6$ tahun berjumlah 80 orang anak. Pengambilan sampel dengan teknik Purposive Sampling. Penelitian dilaksanakan di TK Anak Raja Medan. Teknik pengumpuan data menggunakan teknik portofolio dan observasi. Data portofolio dianalisis secara deskriptif sedangkan data observasi dianalisis untuk menguji hipotesis dengan T-Test Independent menggunakan SPSS 23. Hasil penelitian menunjukkan bahwa rata-rata keterampilan berpikir kreatif anak yang bermain konstruktif dengan emosi positif lebih tinggi dengan nilai rata-rata 15,12 atau berada pada kategori kreatif. Sedangkan keterampilan berpikir kreatif anak dengan emosi negatif dalam bermain konstruktif dikategorikan kurang kreatif, karena memperoleh nilai rata-rata 9,28. Hasil uji parametrik T-Test Independent yaitu Sig. (2-tailed) $0,00<$ dari 0,05 sehingga diputuskan bahwa Ha yang berbunyi “ Terdapat perbedaan keterampilan berpikir kreatif anak yang bermain konstruktif dengan emosi positif dengan anak yang bermain konstruktif dengan emosi negatif' diterima. Penelitian ini menyimpulkan bahwa emosi positif sangat mempengaruhi keterampilan berpikir kreatif anak.

Kata Kunci: Keterampilan Berpikir Kreatif, Emosi, Bermain Konstruktif

\section{PENDAHULUAN}

"Creative thinking is not a talent, it is a skill that can be learn. It empowers people by adding strength to there natural abilities which improves teamwork, productivity and where appropriate profits “ Edward de Bono dalam (Marmol 2017) Individu yang diberi kesempatan berpikir kreatif akan tumbuh sehat dan mampu menghadapi tantangan. Sebaliknya, individu yang tidak diperkenankan berpikir kreatif akan menjadi frustasi dan tidak puas" (Hendriana 2017). Kedua kutipan diatas mengisyaratkan bahwa kreativitas berpikir adalah hal penting yang dapat ditumbuhkembangkan, dapat pula lenyap dari dalam diri seseorang apabila tidak dilatih.

Berpikir kreatif merupakan kemampuan berpikir secara menyebar terhadap beberapa aktivitas dan sasaran, fokus membuat dan mengkomunikasikan hubungan baru yang lebih bermakna (Surya 2015). Seluruh aktivitas berpikir dalam kajian neurosains menyatakan bahwa kemampuan berpikir kreatif diproses secara baik di kedua belahan otak kiri dan kanan karenanya tidak ada anak yang memiliki satu kecenderungan saja, karena otak bekerja simultan (serentak) di seluruh bagian dengan hukum silang otak. Artinya ketika gerak tubuh 
AWLADY: Jurnal Pendidikan Anak

Homepage: www.syekhnurjati.ac.id/jurnal/index.php/awlady

Email : pgrasyekhnurjati@gmail.com

P-ISSN: 2541-4658

E-ISSN: 2528-7427
Vol. 6, No. 2, September 2020

banyak menggunakan kanan berarti otak kirilah yang bekerja dan sebaliknya. Kemampuan berpikir bagi anak usia dini disebut sebagai imajinasi kreatif yakni kemampuan berpikir anak secara optimal melalui pengayaan stimulasi yang imajinatif berupa pemandangan, suara, tekstur, bentuk dan objek karena dapat memperbanyak terbentuknya system neural (sel otak), semakin dalam neurologis yang dapat direpresentasikan maka semakin besar pula kemampuan anak dalam berpikir (Suyadi 2014).

Pendidikan anak usia dini memiliki peran strategis dalam memberikan stimulasi imajinatif pada anak. Salah satunya melalui kegiatan yang bersifat eksploratif. Berdasarkan hasil penelitian (Rosdiana and Subarjah 2016), menyimpulkan bahwa kegiatan eksploratif yang diterapkan sebagai pendekatan dalam meningkatkan keterampilan berpikir kreatif anak lebih tinggi dibandingkan dari pendekatan konvensional. Hal tersebut terjadi karena dalam melakukan eksplorasi anak bebas mengembangkan kemampuan dan imaginasinya, tanpa disadari memberikan stimulus alami dalam mengembangkan keterampilan berpikir kreatif anak, suatu keterampilan yang memiliki andil dalam menentukan masa depannya kelak. Sehingga lembaga pendidikan anak usia dini memegang peranan penting dalam memberikan stimulasi kognitif dengan cara-cara yang mampu membuat anak menjadi senang atau bahagia, karena “Untuk menjadi kreatif, seseorang harus bahagia” (Dauksas 2014).

Proses-proses pemikiran tinggi termasuk berpikir kreatif jarang dilatih dalam penyelenggaraan pendidikan anak usia dini. Pengetahuan bagaimana membaca, berhitung dan menulis lebih ditekankan daripada keterampilan berpikir kreatif. Padahal Egan dalam (Wright 2016) menyatakan '.... Critical thingking rather than knowledge acquisition, ..." Keterampilan berpikir kreatif berkembang dalam diri anak melalui kegiatan pembelajaran berbasis produk. Katz-Buonincontro dalam (Korte and Korte 2014) menyatakan "Creative thinking is developed through learners' hands working with their minds toward knowledge building“. Selanjutnya Wright dalam (Dean and Cheetham n.d.) menyatakan "The imagination is energetically deployed and reaches its peak in children's early years of life, however, it gradually declines as children grow older. But, imagination is precisely what is needed to keep us intellectually flexible and creative in modern societies". Dari kutipankutipan diatas, dapat disimpulkan bahwa penting membangun keterampilan kreatif anak melalui kegiatan berbasis produk, agar dengan demikian imaginasinya ikut berkembang 
AWLADY: Jurnal Pendidikan Anak

Homepage: www.syekhnurjati.ac.id/jurnal/index.php/awlady

Email : pgrasyekhnurjati@gmail.com

P-ISSN: 2541-4658

E-ISSN: 2528-7427

menghasilkan hak-hal baru yang kreatif. Selain menghasilkan hal-hal baru, Sternberg dalam Afifa menyatakan bahwa berpikir kreatif juga merupakan kemampuan melihat satu hubungan yang tidak dilihat orang lain, serta mampu menganalisis idenya atau kualitas karya pribadinya.

(Munandar 2002) menguraikan ciri-ciri dari berpikir kreatif pada anak adalah; (1) Berpikir lancar, dilihat dari prilaku anak yang suka mengajukan pertanyaan, mempunyai banyak gagasan mengenai suatu masalah, dan kemampuan dalam mengungkapkan gagasangagasannya. (2) Berpikir luwes, terlihat dari bagaimana prilaku anak dalam memberikan aneka ragam penggunaan yang tidak lajim terhadap suatu objek, memberikan macam-macam interpretasi terhadap suatu gambar, cerita, atau masalah. (3) Berpikir original, dilihat dari prilaku atau hal-hal imaginative yang tidak pernah dipikirkan orang lain. (4) Keterampilan elaborasi atau memperinci, dilihat dari bagaimana perilaku anak mengembangkan atau memperkaya gagasan orang lain. (5) Keterampilan menilai atau mengevaluasi, dapat dilihat dari bagaimana prilaku anak menentukan pendapat sendiri mengenai suatu hal. Kelima ciriciri diatas, dijadikan indikator dalam mengukur keterampilan berpikir anak dalam bermain konstruktif.

Pembelajaran melalui bermain merupakan salah satu syarat mutlak dalam membelajarkan anak usia dini. Linda dalam (Yus 2010) berpendapat bahwa bermain merupakan peluang bagi anak untuk melakukan berbagai hal. Salah satu jenis permainan yang bersifat eksploratif adalah bermain konstruktif. Jhonson dalam (Papalia 2012) mendifinisikan bermain konstruktif sebagai permainan yang mengandung penggunaan objek atau materi untuk membuat sesuatu. Menurut (Rubin 2001) " The definition of constructive play is the manipulation of objects for purpose of constructing or creating something”. Sedangkan (Ginting 2018) mendifinisikan bermain konstruktif sebagai bentuk permainan menciptakan sesuatu yang nyata dengan cara memanipulasi suatu objek atau bahan-bahan tertentu. Berdasarkan uraian beberapa pendapat tentang bermain konstruktif maka dapat diambil kesimpulan bahwa bermain konstruktif adalah mengubah satu benda atau objek menjadi bentuk lain yang berbeda dengan cara memanipulasinya. Dalam memanipulasi dan menciptakan sesuatu diperlukan keterampilan berpikir kreatif. Sehingga, penerapan bermain konstruktif dipandang tepat untuk mengembangkan berpikir kreatif anak. Bermain konstruktif 
AWLADY: Jurnal Pendidikan Anak

Homepage: www.syekhnurjati.ac.id/jurnal/index.php/awlady

Email : pgrasyekhnurjati@gmail.com

P-ISSN: 2541-4658

E-ISSN: 2528-7427
Vol. 6, No. 2, September 2020

dalam penelitian ini difokuskan pada permainan konstruktif geometri. Dalam penelitian ini anak dihadapkan pada permasalahan yang akan diselesaikan dengan cara memanipulasi guntingan kertas berbentuk geometri (lingkaran, persegi, segitiga dan persegi panjang) menjadi bentuk geometri lainnya dan bentuk alat transportasi. Dilakukan dengan cara menempel pada kertas yang telah disediakan.

Banyak faktor yang dapat mempengaruhi keterampilan berpikir kreatif anak, salah satu adalah kondisi emosi. "As young children develop, their early emotional experiences literally become embedded in the architecture of their brains" (Scientific n.d.). Artinya, emosi merupakan aspek kritis dari perkembangan arsitektur otak secara keseluruhan, dan emosi memiliki konsekuensi yang sangat besar sepanjang hidup. Pernyataan tersebut dibuktikan oleh banyak hasil penelitian. Penelitian (Saputra 2017) yang berjudul: "Hubungan Regulasi Emosi Dengan Hasil Belajar Siswa" menyimpulkan bahwa terhadap hubungan yang sangat signifikan antara regulasi emosi dengan hasil belajar siswa. Hasil penelitian (Mastria, Agnoli, and Corazza 2019) menyimpulkan bahwa keadaan emosional dapat mempengaruhi evaluasi kreativitas ide-ide alternatif eksogen yang dihasilkan melalui pemikiran yang berbeda.

Menurut (Susanto 2011) karakteristik emosi pada anak usia dini ditandai dengan berbagai ciri; (1) Emosi anak bersifat sementara dan lekas berubah; (2) Reaksi yang kuat dan spontan terhadap situasi yang menimbulkan rasa senang atau tidak senang. Anak akan mengutarakan perasaan, keadaan, informasi yang mereka terima apa adanya, tidak ditutup tutupi. Anak mengekspresikan perasaannya secara langsung tentang perasaan senang atau tidak senang, suka atau tidak suka, tanpa ada perasaan bersalah atau takut menyinggung perasaan orang lain; (3) Reaksi emosi anak masih bersifat individual, egois, berubah-ubah pendiriannya, tergantung pada situasi, kondisi, dan dapat dipengaruhi oleh teman, keluarga, ataupun orang sekitar. Perubahan emosi yang cepat dan terus-menerus terstimulus untuk berubah-ubah membawa dampak negatif bagi anak. Penelitian tentang otak menemukan bahwa tubuh menghasilkan zat kimia yang disebut hormon, membantu mengatur fungsi dan reaksi tubuh terhadap lingkungan. Salah satu hormon itu adalah kortisol, horman yang terkait dalam respons terhadap stress dan membantu tubuh merespons terhadap situasi menantang. Terlalu banyak produksi kortisol dalam waktu lama tidak baik dan dapat mengakibatkan 
AWLADY: Jurnal Pendidikan Anak

Homepage: www.syekhnurjati.ac.id/jurnal/index.php/awlady

Email : pgrasyekhnurjati@gmail.com

P-ISSN: 2541-4658

E-ISSN: 2528-7427

masalah pada ingatan dan regulasi diri (Gallagher dalam (Beaty 2013). Pernyataan tersebut sejalan dengan apa yang dinyatakan (Hurlock 2000) "Emosi anak berdampak terhadap aktivitas mental karena kegiatan mental seperti konsentrasi, pengingatan, penalaran, dan lainlain, sangat mudah dipengaruhi oleh emosi yang kuat". Anak-anak menghasilkan prestasi dibawah kemampuan intelektual mereka apabila emosi mereka terganggu. Alangkah baiknya bila emosi anak dapat tetap tenang, stabil, senang, dan bahagia. Strategi dalam membangun emosi positif pada anak adalah dengan cara menyingkirkan atau mengurangi penyebab emosi negatif pada anak (Beaty 2013). Salah satu cara membangun emosi positif pada anak adalah dengan cara menciptakan suasana atau lingkungan yang membuat anak bahagia.

Dari apa yang telah dipaparkan di atas, urgensi pengembangan berpikir kreatif pada anak harus memperhatikan kondisi emosi anak. "As young children develop, their early emotional experiences literally become embedded in the architecture of their brains... Thus, it is essential that young children's feelings get the same level of attention as their thinking" (Scientific n.d.). Sangat penting memberikan perhatian yang sama terhadap perkembangan kognitif dan perkembangan emosi anak. Dengan kata lain, tuntutan lingkungan akan perkembangan kognitif anak seharusnya didahului oleh kewajiban untuk mengkondisikan emosi anak dengan baik.

Kondisi emosi anak, baik emosi positif atau emosi negatif memungkinkan adanya perbedaan keterampilan berpikir kreatif dalam menciptakan sesuatu melalui kegiatan bermain konstruktif. Rumusan masalah dalam penelitian ini adalah: Apakah ada perbedaan keterampilan berpikir kreatif anak usia $5-6$ tahun ditinjau dari emosi dalam bermain konstruktif ? Penelitian ini bertujuan untuk melihat sejauh mana perbedaan keterampilan berpikir kreatif anak usia dini ditinjau dari emosi positif dan emosi negatif dalam bermain konstruktif.

\section{METODOLOGI}

Penelitian ini menggunakan pendekatan deskriptif kuantitatif. Populasi penelitian adalah seluruh anak kelompok B dengan usia 5-6 tahun dengan jumlah 80 orang anak. Penelitian dilaksanakan di TK Anak Raja jalan Flamboyan Medan. Sampel penelitian diambil dengan teknik Purposive Sampling. Adapun langkah-langkah dalam menentukan sampel penelitian adalah: (1) Peneliti melakukan pengamatan terhadap kompetensi kecerdasan emosi 
AWLADY: Jurnal Pendidikan Anak

Homepage: www.syekhnurjati.ac.id/jurnal/index.php/awlady

Email : pgrasyekhnurjati@gmail.com

P-ISSN: 2541-4658

E-ISSN: 2528-7427

populasi dengan terlebih dahulu memberikan label berbentuk angka untuk memudahkan perekaman atau pencatatan hasil pengamatan yang dilakukan menggunakan lembar observasi kompetensi emosi anak yang merujuk pada (Scientific n.d.), Dimana emosional terdiri dari tiga kompetensi yang saling terkait, yaitu : ekspresi emosi; pengetahuan emosi, dan regulasi emosi. (2) mengurutkan data hasil pengamatan terhadap kecerdasan emosi anak dari yang tertinggi sampai terendah. 3) menetapkan 25 data tertinggi menjadi kelompok sampel anak yang akan bermain konstruktif dengan emosi positif dan 25 data terendah menjadi sampel anak akan bermain konstruktif dengan emosi negatif. Dalam pelaksanaan penelitian, kelompok anak yang bermain konstruktif dengan emosi negatif akan dipimpin oleh peneliti, orang yang tidak dikenal anak. Peneliti akan mengkondisikan suasana kelas yang tertib dan dikendalikan penuh oleh peneliti, sehingga mempengaruhi emosi anak.

Definisi operasional keterampilan berpikir kreatif dalam penelitian ini adalah kemampuan anak dalam menggunakan pikirannya dalam membuat, menciptakan dan memodifikasi sesuatu menjadi berbeda dan memiliki keunikan tersendiri. Tingkat keterampilan berpikir kreatif sesuai pendapat (Siswono and Budayasa 2006) yang membedakan keterampilan berpikir kreatif menjadi: 1) Tidak kreatif; 2) Kurang kreatif; 3) Cukup kreatif; 4) Kreatif; 5) Sangat kreatif. Sangat kreatif ditunjukkan dari hasil karya anak yang menggambarkan kemampuan mentalnya dalam berpikir lancar, orisinal, memiliki rasa ingin tahu yang besar, bersikap aktif, tertantang dan berani mengambil resiko. Tingkatan keterampilan berpikir kreatif tersebut disesuaikan dengan skor tertinggi hasil observasi yang terdiri dari 21 item.

Teknik pengumpulan data menggunakan instrument portofolio dan lembar observasi keterampilan berpikir kreatif anak. Instrumen portofolio digunakan untuk mendeskripsikan produk atau hasil karya dari keterampilan kreatif anak dalam mengkonstruksi kepingan geometri menjadi suatu bentuk yang original, mampuan membuat hal yang berbeda dengan orang lain dan dapat menemukan konsep baru dari tugas yang diberikan. Sedangkan lembar observasi digunakan untuk memperoleh seluruh data keterampilan berpikir kreatif anak yang terdiri dari lima indikator, yaitu: berpikir lancar, berpikir luwes, berpikir orisinal, berpikir elaboratif, dan berpikir evaluatif.

\section{HASIL DAN PEMBAHASAN}


AWLADY: Jurnal Pendidikan Anak

Homepage: www.syekhnurjati.ac.id/jurnal/index.php/awlady

Email : pgrasyekhnurjati@gmail.com

P-ISSN: 2541-4658

E-ISSN: 2528-7427

Keterampilan berpikir kreatif pada anak yang bermain konstruktif dengan emosi positif dengan anak yang bermain konstruktif dengan emosi negatif dirangkum pada Tabel di bawah ini.

Tabel. Keterampilan Berpikir Kreatif Anak Dengan Emosi Positif Dan Negatif

\begin{tabular}{|c|c|c|}
\hline Sampel & $\begin{array}{l}\text { Data Keterampilan Berpikir Kreatif Anak dengan } \\
\text { Emosi Positif }\end{array}$ & $\begin{array}{c}\text { Data Keterampilan Berpikir Kreatif Anak } \\
\text { dengan Emosi Negatif }\end{array}$ \\
\hline 1 & 17 & 12 \\
\hline 2 & 12 & 3 \\
\hline 3 & 14 & 5 \\
\hline 4 & 17 & 12 \\
\hline 5 & 17 & 11 \\
\hline 6 & 18 & 7 \\
\hline 7 & 12 & 13 \\
\hline 8 & 8 & 6 \\
\hline 9 & 21 & 11 \\
\hline 10 & 10 & 4 \\
\hline 11 & 16 & 8 \\
\hline 12 & 7 & 9 \\
\hline 13 & 18 & 10 \\
\hline 14 & 18 & 11 \\
\hline 15 & 12 & 11 \\
\hline 16 & 16 & 10 \\
\hline 17 & 15 & 7 \\
\hline 18 & 18 & 12 \\
\hline 19 & 14 & 8 \\
\hline 20 & 18 & 12 \\
\hline 21 & 16 & 14 \\
\hline 22 & 13 & 8 \\
\hline 23 & 19 & 9 \\
\hline 24 & 15 & 7 \\
\hline 25 & 17 & 12 \\
\hline$\sum$ & 378 & 232 \\
\hline X & 15,12 & $\mathbf{9 , 2 8}$ \\
\hline
\end{tabular}


AWLADY: Jurnal Pendidikan Anak

Homepage: www.syekhnurjati.ac.id/jurnal/index.php/awlady

Email : pgrasyekhnurjati@gmail.com

P-ISSN: 2541-4658

E-ISSN: 2528-7427

Dari Tabel diketahui bahwa rata-rata keterampilan berpikir kreatif anak yang bermain konstruktif dengan emosi positif adalah 15,12. Apabila dikonversikan ke Tabel 1 tentang kriteria keterampilan berpikir kreatif, maka secara keseluruhan anak yang bermain konstruktif dengan emosi positif dapat dikategorikan kreatif. Sedangkan nilai rata-rata keterampilan berpikir kreatif kelompok anak yang bermain konstruktif dengan emosi negatif adalah 9,28. Artinya, secara keseluruhan keterampilan berpikir kreatif anak yang bermain konstruktif dengan emosi negatif berada pada kategori kurang kreatif. Berikut ini adalah data frekuensi untuk mendeskripsikan data keterampilan berpikir kreatif kelompok anak yang bermain konstruktif dengan emosi positif dan anak yang bermain konstruktif dengan emosi negatif.

Tabel. Keterampilan berpikir kreatif anak dengan emosi positif

\begin{tabular}{|l|l|l|l|l|}
\hline \multirow{2}{*}{$\begin{array}{l}\text { Kategori Keterampilan berpikir } \\
\text { kreatif }\end{array}$} & \multicolumn{4}{|l|}{ Frekuensi } \\
\cline { 2 - 6 } & \multicolumn{2}{|l|}{ Relatif } & \multicolumn{2}{l|}{ Kumulatif } \\
\cline { 2 - 6 } & $\mathbf{f}$ & $\mathbf{( \% )}$ & $\mathbf{f}$ & $\mathbf{( \% )}$ \\
\hline Tidak Kreatif & 0 & 0 & 0 & 0 \\
\hline Kurang Kreatif & 2 & 8 & 2 & 8 \\
\hline Cukup Kreatif & 5 & 20 & 7 & 28 \\
\hline Kreatif & 11 & 44 & 18 & 72 \\
\hline Sangat Kreatif & 7 & 28 & 25 & 100 \\
\hline TOTAL & 25 & 100 & & \\
\hline
\end{tabular}

Tabel di atas mengambarkan bahwa anak yang bermain konstruktif dengan emosi yang positif tidak ada anak yang tidak kreatif. Terdapat 2 orang anak (8\%) yang kurang kreatif. 5 orang anak (20\%) cukup kreatif, 11 orang anak (44\%) anak yang kreatif, dan 7 orang anak (28\%) yang sangat kreatif. Sebanyak 18 orang anak atau $72 \%$ dari seluruh kelompok anak yang bermin konstruktif dengan emosi positif berada pada kategori kreatif. Berikut ini merupakan diagram yang menggambarkan keterampilan berpikir kreatif anak yang bermain konstruktif dengan emosi positif.

Tabel di bawah mengambarkan keterampilan berpikir kreatif anak yang bermain konstruktif dengan emosi yang negatif. 3 orang anak (12\%) tidak kreatif. Terdapat 9 orang anak (36\%) yang kurang kreatif. 12 orang anak (48\%) cukup kreatif, hanya 1 orang anak (4 $\%)$ yang kreatif, dan tidak ada anak yang sangat kreatif. Berikut ini merupakan diagram yang 
AWLADY: Jurnal Pendidikan Anak

Vol. 6, No. 2, September 2020

Homepage: www.syekhnurjati.ac.id/jurnal/index.php/awlady

Email : pgrasyekhnurjati@gmail.com

P-ISSN: 2541-4658

E-ISSN: 2528-7427

menggambarkan tingkat keterampilan berpikir kreatif anak dalam bermain konstruktif dengan emosi negatif.

Tabel. Keterampilan berpikir anak dengan emosi negatif

\begin{tabular}{|l|l|l|l|l|}
\hline \multirow{2}{*}{$\begin{array}{l}\text { Kategori Keterampilan } \\
\text { berpikir kreatif }\end{array}$} & \multicolumn{4}{l|}{ Frekuensi } \\
\cline { 2 - 6 } & \multicolumn{2}{l|}{ Relatif } & \multicolumn{2}{l|}{ Kumulatif } \\
\cline { 2 - 6 } & $\mathbf{f}$ & $\mathbf{( \% )}$ & $\mathbf{f}$ & $\mathbf{( \% )}$ \\
\hline Tidak Kreatif & 3 & 12 & 3 & 12 \\
\hline Kurang Kreatif & 9 & 36 & 12 & 48 \\
\hline Cukup Kreatif & 12 & 48 & 24 & 96 \\
\hline Kreatif & 1 & 4 & 25 & 100 \\
\hline Sangat Kreatif & 0 & 0 & 0 & 0 \\
\hline TOTAL & 25 & 100 & & \\
\hline
\end{tabular}

Apabila digambarkan dalam bentuk diagram batang, maka perbandingan keterampilan berpikir kreatif anak ditinjau dari kondisi emosinya dalam bermain konstruktif dapat dilihat pada Gambar 3 di bawah.

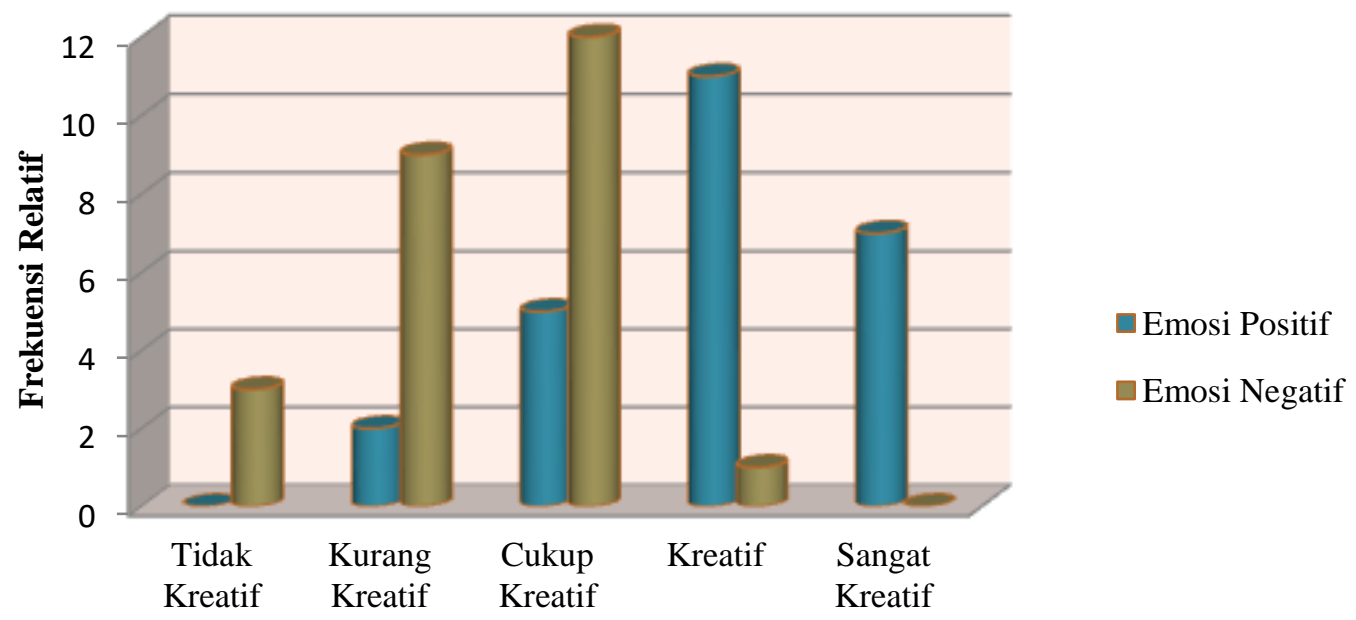

Gambar Perbedaan Keterampilan Berpikir Kreatif Anak Ditinjau Dari kondisi emosi 
Hasil Analisis T-Test Independent

\begin{tabular}{|c|c|c|c|c|c|c|c|c|c|c|}
\hline & \multicolumn{2}{|c|}{\begin{tabular}{|l|} 
Levene's Test \\
for Equality of \\
Variances
\end{tabular}} & \multicolumn{7}{|c|}{ t-test for Equality of Means } \\
\hline & & \multirow[b]{2}{*}{$F$} & \multirow[b]{2}{*}{ Sig. } & \multirow[b]{2}{*}{$\mathrm{t}$} & \multirow[b]{2}{*}{ df } & \multirow{2}{*}{$\begin{array}{l}\text { Sig. } \quad(2- \\
\text { tailed })\end{array}$} & \multirow{2}{*}{$\begin{array}{l}\text { Mean } \\
\text { Difference }\end{array}$} & \multirow{2}{*}{$\mid \begin{array}{l}\text { Std. Error } \\
\text { Difference }\end{array}$} & \multicolumn{2}{|c|}{$\begin{array}{l}95 \% \text { Confidence } \\
\text { Interval of the } \\
\text { Difference }\end{array}$} \\
\hline & & & & & & & & & Lower & Upper \\
\hline $\begin{array}{l}\text { keterampilan } \\
\text { berpikir kreatif }\end{array}$ & $\begin{array}{l}\text { Equal } \\
\text { variances } \\
\text { assumed }\end{array}$ & .392 & .534 & 6.464 & 48 & .000 & 5.84000 & .90340 & 4.02359 & 7.65641 \\
\hline & $\begin{array}{l}\text { Equal } \\
\text { variances not } \\
\text { assumed }\end{array}$ & & & 6.464 & 46.641 & .000 & 5.84000 & .90340 & 4.02222 & 7.65778 \\
\hline
\end{tabular}

Berdasarkan analisis T-Test Independent diperoleh nilai Sig. (2-tailed) $0,00<$ dari 0,05. Sehingga Ha diterima dan Ho ditolak. Terdapat perbedaan keterampilan berpikir kreatif anak yang bermain konstruktif dengan emosi positif dengan anak yang bermain konstruktif dengan emosi negatif. Hasil penelitian ini sejalan dengan pendapat (Dauksas 2014) yang menyatakan bahwa seseorang akan menghasilkan peringkat kreativitas yang lebih tinggi ketika berada dibawah keterlibatan emosional positif daripada kondisi negatif atau netral. Peneliti menemukan bahwa kecenderungan emosi positif anak mempengaruhi evaluasi kreativitas ide-ide alternatif anak, sehingga memungkinkan individu untuk bereksplorasi dan menghasilkan suatu kreativitas tinggi. 
Gambar 4 berikut Merupakan hasil karya salah satu anak dalam dua kali kegiatan. Gambar bagian bawah adalah bentuk lingkaran, persegi, persegi panjang, dan segitiga sebagai dudukan anak dalam mengkonstruksi kepingankepingan geometri menjadi bentuk sesuai lembar kerja yang diberikan. Sedangkan gambar bagian atas adalah kepingan geometri yang ditugaskan untuk disusun menjadi bentuk alat transportasi. Dari kedua hasil karya anak, tergambar kondisi emosi anak yang merasa tidak nyaman sehingga mempengaruhi aktivitas mental dan output hasil belajarnya. (Scientific n.d.) Menyatakan “" The emotional health of young children is closely tied to the social and emotional characteristics of the environments in which they live ". Artinya adalah

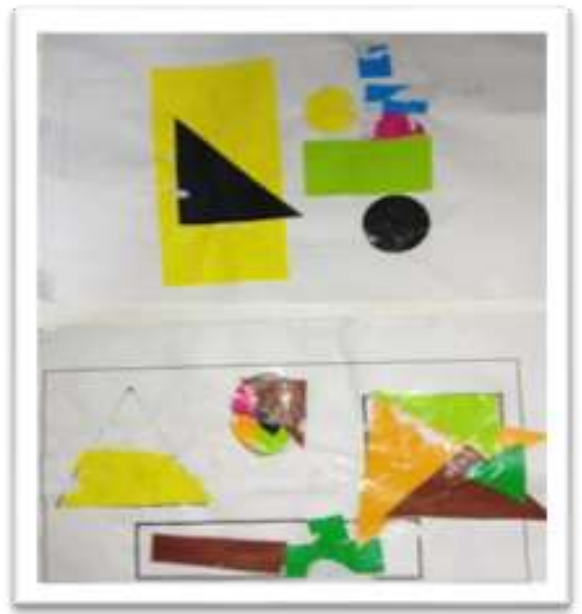

Gambar 4. Interpretasi Emosi Negatif dalam Bermain Konstruktif bahwa kesehatan emosional anak terkait erat dengan karakteristik social dan emosional dari lingkungan tempat dimana mereka tinggal. Selain itu, anak tersebut menunjukkan sikap yang kurang antusias, membutuhkan waktu yang lebih lama dalam mengerjakan tugasnya. Emosi tidaklah satu-satunya faktor yang mempengaruhi keterampilan berpikir kreatif anak dalam menciptakan bentuk transportasi melalui kegiatan bermain konstruktif. Faktor lainnya adalah sistem keterlibatan sosial fisik anak dengan lingkungannya. Pada pelaksanaannya, sempel penelitian yang bermain konstruktif dengan emosi negative, sedapat mungkin dibatasi ruang dan geraknya dalam berkomunikasi dengan temannya. Keterbatasan gerak fisik dan kontak social ternyata berperan terhadap anak. (Panksepp 2011) menyatakan: "Young children, like most immature mammals, have robust urges for physical play, which naturally lead to chasing, romping and wrestling, accompanied routinely by joyous shrieking and laughter" Anak memiliki dorongan yang kuat untuk bermain, aktif secara fisik. Itu adalah salah satu karakteristik. Anak usia dini. Ketika dorongan tersebut dibatasi, maka berpengaruh terhadap emosi dan aktivitas mental anak.

Gambar 5 dibawah Merupakan hasil karya anak yang bermain konstruktif dengan emosi positif. Emosi positif yang ditimbulkan oleh suasana yang kondusif yang tercipta dari senyuman, keramahan guru dan peneliti, adanya pendekatan untuk membangun kelekatan 
sebelum kegiatan bermain konstruktif dilaksanakan. Membangun perasaan nyaman anak sebelum belajar, secara tidak langsung memberikan stimulus yang baik (Lewis 2011) menyatakan “ ... Approach refers to behaviours and facial expressions that move a child towards stimuli..." Sehingga amatlah penting untuk lebih dahulu membangun emosi positif anak sebelum menghadapkan mereka pada suasana kegiatan pembelajaran. Emosi dan perkembangan kognitif anak harus mendapat perhatian yang sama agar tujuan pembelajaran dapat tercapai dengan baik, sebagaimana yang dinyatakan Posner, M. Rothbart, M dalam (Scientific n.d.) menyatakan: “The

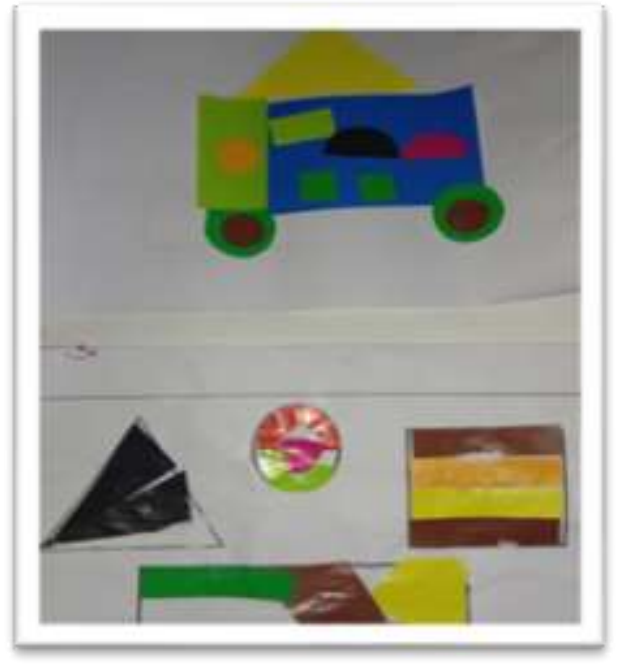

Gambar 5 Interpretasi Emosi Positif dalam bermain konstruktif

circuits that are involved in the regulation of emotion are highly interactive with those that are associated with "executive functions" (such as planning, judgment, and decisionmaking), which are intimately involved in the development of problem-solving skills during the preschool years". In terms of basic brain functioning, emotions support executive functions when they are well regulated but interfere with attention and decision- making when they are poorly controlled".

Dari kutipan di atas, jelas bahwa menjaga emosi anak tetap positif merupakan syarat mutlak agar fungsi eksekutif otaknya dapat bekerja dengan baik, merasa nyaman dalam mengekspresikan dirinya, tanpa malu-malu atau takut mengajukan pertanyaan akan hal-hal yang tidak dipahaminya. Gambar 5. bagian atas dan gambar bagian bawah memiliki unsur keteraturan sekalipun keterampilan berpikir kreatif anak belum terlihat secara menonjol dalam mengkonstruksi guntingan-guntingan geometri menjadi bentuk geometri yang diharapkan dengan cara merancang, mengingat, mencari alternatif bentuk penyelesaian masalah. Hal ini terkait dengan perkembangan kognitif anak yang berada pada tahap intuitif. Tahap dimana anak telah mengenal objek berdasarkan pengenalan secara simbolik, namun masih terbatas pada hasil imajinasi atau intuisi, belum dihasilkan dari pemikiran proses terjadinya objek tersebut, dalam hal ini proses membentuk geometri dan bentuk kendaraan (Mutmainnah 2019). 
AWLADY: Jurnal Pendidikan Anak

Homepage: www.syekhnurjati.ac.id/jurnal/index.php/awlady

Email : pgrasyekhnurjati@gmail.com

P-ISSN: 2541-4658

E-ISSN: 2528-7427

Lingkungan berperan dalam membangun keterampilan berpikir kreatif. Anak akan lebih leluasa dalam mengerjakan tugas dengan caranya sendiri, tidak merasa sungkan atau malu dalam menjelaskan apa yang dibuatnya ketika dia berada dilingkungan yang tidak asing dan melekat dalam dirinya. Ketika anak berada pada lingkungan yang baru, lingkungan yang dikendalikan oleh orang asing yang tidak dikenalnya, akan membuat anak merasa kurang nyaman apalagi bila orang tersebut memperlakukannya lingkungan anak tersebut dengan cara yang tidak biasa. Anak-anak akan merasa terancam, tidak berani dengan leluasa bertanya dan melakukan hal-hal yang ada dalam imaginasinya dikarenakan anak tersebut takut disalahkan atau takut apa yang dikerjakannya adalah salah. Hal ini tentu mempenyaruhi keterampilan elaboratif dan evaluatif anak, keterampilan dimana anak dengan leluasa mengajukan pertanyaan, memberi pendapat, serta mempertanyakan hasil karya atau pendapat temannya.

Orisinalitas merupakan salah satu indikator dari keterampilan berpikir kreatif. Kemampuan anak dalam membuat sesuatu yang baru, lain daripada yang lain tidak sertamerta timbul dengan sendirinya. Anak membutuhkan dukungan dalam merealisasikan idenya. Dukungan dalam bentuk kebebasan dalam mengeksplorasi kepingan geometri yang diberikan. Gambar 6 merupakan keterampilan berpikir kreatif kelompok anak yang bermain konstruktif dengan emosi negatif. Sebesar $76 \%$ (19 orang) anak mengkonstruksi bentuk alat transportasi dengan desain yang hampir sama dan dengan satu variasi bentuk. Keterampilan
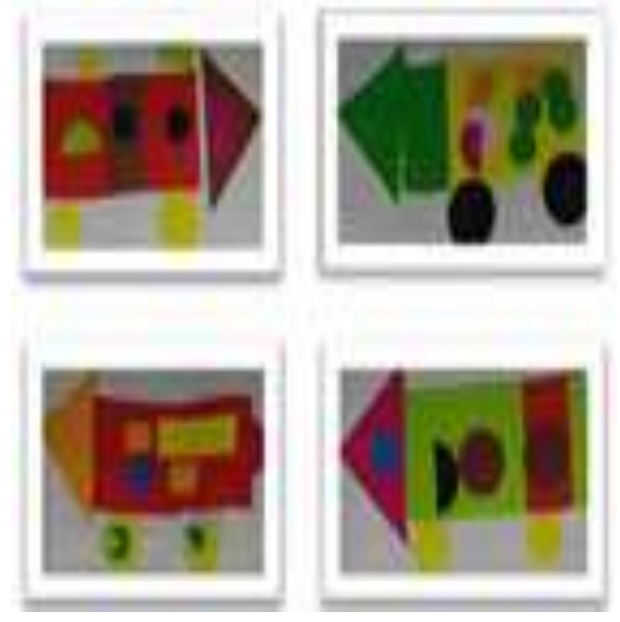

\begin{tabular}{|c|}
\hline Gambar 6. \\
Interpretasi Emosi Positif dalam \\
bermain konstruktif
\end{tabular}
berpikir anak yang terlihat dari hasil karyanya tidak sepenuhnya sama antara satu anak dengan anak yang lainnya. Namun, ketika peneliti menanyakan atau mengajak anak menceritakan hasil karyanya, anak cenderung diam dan tidak mampu menjelaskan hasil karyanya, menunjukkan ekspresi malu atau takut dengan kepala menunduk dan bersandar kepada temannya. Temuan peneliti, keterampilan berpikir kreatif anak pada kelompok anak yang bermain konstruktif dengan emosi negatif, Mayoritas anak tidak percaya diri dalam mengkonstruksi bentuk transportasi. Anak yang satu melihat bahkan mencontoh apa yang 
AWLADY: Jurnal Pendidikan Anak

Vol. 6, No. 2, September 2020

Homepage: www.syekhnurjati.ac.id/jurnal/index.php/awlady

Email : pgrasyekhnurjati@gmail.com

P-ISSN: 2541-4658

E-ISSN: 2528-7427

dikerjakan temannya. Anak-anak tidak percaya diri, gugup dan gelisah. Kegelisahan hati anak terlihat dari lem yang digunakan untuk menempel terlalu banyak, anak kesulitan dalam mengontrol koordinasi tangan dan matanya.

Anak yang bermain konstruktif dengan emosi positif secara keseluruhan menghasilkan tujuh variasi bentuk yang berbeda seperti yang terlihat pada gambar 7. Sebanyak 3 orang anak (12\%) dari kelompoknya yang menghasilkan karya dengan bentuk seperti gambar 7 bagian 1. Sebanyak 5 orang anak ( $20 \%$ ) menghasilkan karya dengan bentuk gambar seperti gambar 7 bagian 2. Sebanyak 13 orang anak ( $52 \%$ ) yang menghasilkan karya seperti gambar 7 bagian 3 . Dan masing-masing satu orang anak (masing-masing 4

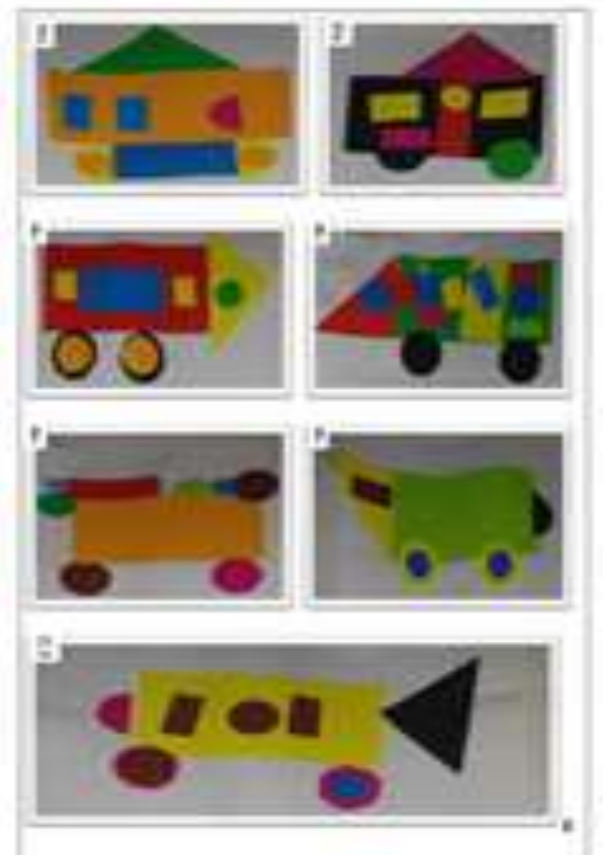

Gambar 7.

Originalitas karya anak dengan emosi negatif \%) yang menghasilkan karya seperti gambar 7 bagian 4,5, 6, dan 7. Gambar 7 bagian 1 merupakan hasil karya seorang anak berinisial SG. Dia menceritakan tentang apa yang dibuatnya. "Ini pesawat astronot,dua pintu biru satu jendelanya” jelas SG. Mengapa pintunya ada dua nak?, "Supaya kalau tabrakan astronotnya bisa cepat-cepat keluar" jawab SG. Kalau jendelanya, kenapa yang bentuk setengah lingkaran seperti ini? Kenapa tidak yang persegi saja?, “ Jendelanya tidak bisa dibuka, kalau dibuka pesawat astronotnya meledak” jelas SG. Ada persamaan antara gambar 7 bagian 1 dengan gambar 7 bagian 2. Persamaannya terletak pada guntingan segitiga pada bagian paling atas. Gambar 7 bagian 2 merupakan hasil karya anak berinisial $\mathrm{AD}$. AD menceritakan bahwa yang dibuatnya adalah rumah yang bisa berjalan seperti bus. Kenapa atap rumahnya dipinggir kanan nak?, “ Iya, karena disini (sambil menunjuk sebelah kiri yang tidak beratap) tempat pak supirnya”. Pak supirnya apa tidak basah atau kepanasan kalau tidak pakai atap nak?. "Iya, diakan bisa masuk ke rumah ambil topi sama payung, disini ada pintunya bu, bisa supirnya langsung masuk ke rumah', jelas AD. Gambar 7 bagian 3 adalah hasil karya anak berinisial YT, Hasil karya YT memiliki kesamaan bentuk dengan 14 orang anak lainnya. Yang membedakan adalah penjelasan YT tentang hasil 
AWLADY: Jurnal Pendidikan Anak

Homepage: www.syekhnurjati.ac.id/jurnal/index.php/awlady

Email : pgrasyekhnurjati@gmail.com

P-ISSN: 2541-4658

E-ISSN: 2528-7427
Vol. 6, No. 2, September 2020

karyanya. YT buat apa nak? Ini motor (sebutan mobil di Medan) perang bu. Wah.. bannya besar sekali ya, kenapa ban mobilnya besar nak?, YT hanya tersenyum tanpa menjawab. Yang ini apa nak (peneliti menunjuk guntingan bentuk persegi berwarna biru) ? "Ini pintunya" jawab YT. Pintu mobil perang bukannya di atas atau di belakang nak?. "Ia. disini aja biar nempak (kelihatan) tentara yang sakit supaya bisa dibantu, dimasukkan dari sini (sambil menunjuk pintu mobil perangnya).

Gambar 7 bagian 4 merupakan hasil karya anak berinisial RS. Satu-satunya anak yang menghasilkan karya bentuk transportasi dengan porposional. Ini bentuk apa nak? " Truk barang bu” jawab RS. Truk barangnya ada gambarnya ya nak?, “ Bukan bu, ini kotak-kotak barang yang ada dalam truk barang" jelas RS. RS memvisualisasikan yang ada dalam imaginasinya. RS tidak hanya mampu membuat ide

truk barang, tetapi juga membuat barang-barang yang ada dalam kotak yang diwakili oleh guntingan geometri. RS pernah lihat truk barang?, "Ia. Aku punya truk barang di rumah" jawab RS. Ternyata orang tua RS merupakan pengusaha distributor sembako ke beberapa wilayah di kota Medan. Dalam hal ini, lingkungan tempat tinggal RS berperan dalam mengembangkan imajinasinya. Gambar 7 bagian 5 adalah hasil harya anak dengan inisial NS. Ini apa nak? " Gerobak sampah bu” jawab NS. Gerobak sampah itu, transportasi ya nak?, "Ia.. kalau udah penuh gerobaknya kan datang motor besar. Jawab NS. NS merasa bahwa gerobak sampah adalah alat transportasi, hal ini menggambarkan perkembangan berpikir semilogical reasoning. Dimana anak menjelaskan kejadian sehari-hari dengan melakukan personifikasi (Mutmainnah. 2015).

Gambar 7 bagian 6 adalah hasil karya anak dengan inisial FH. FH tidak menjelaskan hasil karyanya, dia terlihat malu dan berusaha menjauh. Berdasarkan keterangan dari guru kelas, diperoleh informasi bahwa FH adalah anak yang berbakat atau menonjol dalam hal seni seperti menggambar, mewarnai. Tetapi FH bermasalah dalam hal berkomunikasi. Gambar 7 bagian 7 adalah hasil karya anak dengan inisial DK. Gambar apa ini nak? "Mobil semen" jawab DK. Mobil semen itu bagaimana nak? "Itu bu, mobil yang dipakai untuk bangun rumah, yang bisa dimasukkan batu, pasir sama semen. Disini (menunjukan guntingan segitiga) masukkan semennya' jawab DK. Bagi DK mesin penggiling semen adalah salah satu alat transportasi. Peneliti menjelaskan kepada DK bahwa itu bukan alat transportasi, tetapi 
AWLADY: Jurnal Pendidikan Anak

Homepage: www.syekhnurjati.ac.id/jurnal/index.php/awlady

Email : pgrasyekhnurjati@gmail.com

P-ISSN: 2541-4658

E-ISSN: 2528-7427

mesin bangunan. Selanjutnya peneliti bertanya kepada DK, “ Dimana DK lihat mesin seperti itu nak? “ aku lihat di depan rumahku, ada orang bangun rumah” kata DK.

Penjelasan dan ide dari RS, NS, dan DK bersumber dari lingkungan dan pengalamannya, dengan kematangan berpikir masing-masing. Lingkungan dan pengalaman berperan dalam membentuk ide atau imajinasi anak. Terjadi sesuatu didalam diri anak ketika mereka menemukan sesuatu yang berkesan bagi dirinya. Truk barang memberikan kesan tersendiri kepada RS. Rasa takjub terhadap muatan yang banyak, yang bisa dimasukkan ke dalam truk barang. RS merasa takjub ketika suatu barang yang menurutnya tidak muat lagi dimasukkan kedalam truk, ternyata masih dapat dimasukkan. Gerobak sampah berwarna kuning, memberi kesan tersendiri bagi NS sehingga memancing imajinasinya mengkonstruk guntingan geometri menjadi gerobak sampah. Mobil semen yang diceritakan DK menggambarkan bagaimana benda itu sangat berkesan baginya. Bentuk alat transportasi yang dibuat ketujuah anak di atas merupakan keterampilan elaborative sebagai alah satu indikator keterampilan berpikir kreatif. Keterampilan dimana anak dapat menemukan konsep baru dari tugas yang diberikan. Kemampuan anak menjelaskan hasil karyanya merupakan salah satu indikator keterampilan berpikir dalam aspek berpikir evaluatif, anak tidak malu dalam mengajukan pendapat dan pertanyaan serta mempertanyakan jawaban atau hasil karya temannya.

\section{SIMPULAN}

Hasil penelitian menyimpulkan bahwa terdapat perbedaan keterampilan berpikir kreatif anak yang bermain konstruktif dengan emosi positif dibandingkan anak yang bermain konstruktif dengan emosi negatif. Rata-rata nilai keterampilan berpikir kreatif kelompok anak yang bermain konstruktif dengan emosi positif adalah 15,12 atau dikategorikan kreatif, dengan rincian 11 orang anak berkategori kreatif dan 7 orang sangat kreatif. Sedangkan ratarata nilai keterampilan berpikir kreatif kelompok anak yang bermain konstruktif dengan emosi negatif adalah 9,25 atau secara keseluruhan dikategorikan cukup kreatif, dengan rincian 1 orang anak dikategorikan kreatif dan tidak ada anak yang sangat kreatif. Dengan demikian disimpulkan bahwa kondisi emosi sangat berpengaruh terhadap keterampilan berpikir kreatif anak. Disarankan kepada guru dan orang tua agar mengkondisikan emosi anak sebelum 
kegiatan pembelajaran, berada pada kondisi emosi yang positif. Sehingga tujuan pembelajaran dapat tercapai dengan optimal.

\section{DAFTAR PUSTAKA}

Beaty, Janice. 2013. Observasi Perkembangan Anak Usia Dini. Tujih. Jakarta: Kencana.

Dauksas, Linda. 2014. "Discovering Shapes and Space in Preschool _ NAEYC." https://www.naeyc.org/resources/pubs/tyc/apr2014/discovering-shapes-and-spacepreschool.

Dean, Jo, and Keri Cheetham. "Supporting Children's Critical and Creative Thinking Skills in the Early Years."

Ginting, Meta Br. 2018. "Membangun Pengetahuan Anak Usia Dini Melalui Permainan Konstruktif Berdasarkan Perspektif Teori Piaget." Jurnal Caksana-Pendidikan Anak Usia Dini 1(2): 159-71. http://trilogi.ac.id/journal/ks/index.php/PAUD/article/view/190/156.

Hendriana, H.Heris. 2017. Hard Skills Dan Soft Skills Matematik Siswa. Bandung: Rafika Aditama.

Hurlock, Elizabeth B. 2000. Perkembangan Anak. 2nd ed. Jakarta: Erlangga.

Korte, Laurie E, and Laurie Korte. 2014. "Collaborative and Creative Thinking Skill Development Through the Design of Wearable Technologies This Is to Certify That the Doctoral Dissertation By."

Lewis, Michael. 2011. "Michael Lewis, PhD, Institute for the Study of Child Development, UMDNJ-Robert Wood Johnson Medical School, USA." (December).

Marmol, Lorenzo Del. 2017. "11 Useful Tricks to Improve Your Creative Thinking." Creative thinking, What is creativity. https://creativecorporateculture.com/11-usefultricks-to-improve-creative-thinking/.

Mastria, Serena, Sergio Agnoli, and Giovanni Emanuele Corazza. 2019. "How Does Emotion Influence the Creativity Evaluation of Exogenous Alternative Ideas?" PLoS ONE 14(7).

Munandar, Utami. 2002. Kreatifitas Dan Keberbakatan. Jakarta: Erlangga.

Mutmainnah, Mutmainnah. 2019. "Lingkungan Dan Perkembangan Anak Usia Dini Dilihat Dari Perspektif Psikologi." Gender Equality: International Journal of Child and Gender Studies 5(2): 15.

Panksepp, Jaak. 2011. "Child Development and the Emotional Circuits of Mammalian Brains Introduction and Subject." : 1-4.

Papalia, Diane E. 2012. Human Development. Sembilan. Jakarta: Kencana.

Rosdiana, Daniar, and Herman Subarjah. 2016. "Pendekatan Eksploratif Untuk Meningkatkan Kemampuan Berpikir Kreatif Dan Disposisi Matematis.” Pendekatan Eksploratif Untuk Meningkatkan Kemampuan Berpikir Kreatif Dan Disposisi Matematis 1(1): 231-40.

Rubin, Kenneth H. 2001. "The Play Observation Scale (POS)." The University of Waterloo (Revised): 1-23. https://utsc.utoronto.ca/ marksch/psyc26/The Play Observation Scale.pdf\%0Ahttp://www.utsc.utoronto.ca/ marksch/psyc26/The Play Observation Scale.pdf.

Saputra, Siska. 2017. "Hubungan Regulasi Emosi Dengan Hasil Belajar Siswa." Konselor 6(3): 96.

Scientific, National. "Children's Emotional Development Is Built into the Architecture of 
AWLADY: Jurnal Pendidikan Anak

Homepage: www.syekhnurjati.ac.id/jurnal/index.php/awlady

Email : pgrasyekhnurjati@gmail.com

P-ISSN: 2541-4658

E-ISSN: 2528-7427
Vol. 6, No. 2, September 2020

Their Brains."

Siswono, T. Y. E., and I. K. Budayasa. 2006. "Implementasi Teori Tentang Tingkat Berpikir

Kreatif Dalam Matematika." Seminar Konferensi Nasional Matematika XIII dan

Konggres Himpunan Matematika Indonesia di Jurusan Matematika FMIPA Universitas

Negeri Semarang: 1-16.

https://tatagyes.files.wordpress.com/2009/11/paper06_implementasiteori.pdf\%0A.

Sugiyono. 2014. Metode Penelitian Pendekatan Kuantitatif, Kualitatif, Dan R\&D. Bandung:

Alfabeta.

Surya, Muhamad. 2015. Strategi Kognitif Dalam Proses Pembelajaran. Pertama. Bandung: Alfabeta.

Susanto, Ahmad. 2011. Perkembangan Anak Usia Dini. Jakarta: Kencana.

Suyadi. 2014. Teori Pembelajaran Anak Usia Dini Dalam Kajian Neurosains. Bandung:

Remaja Rosdakarya.

Wright, Susan. 2016. “Creativity: Meaning-Making and Representation.” (January).

Yus, Anita. 2010. Penilaian Perkembangan Belajar Anak TK. Jakarta: Kencana. 